\title{
Correlation of lineaments (magnetic and topographic) and Phanerozoic brittle structures with Precambrian shear zones from the basement of the Paraná Basin, Santa Catarina State, Brazil
}

\author{
Correlação de lineamentos (magnéticos e topográficos) e estruturas \\ rúpteis Fanerozoicas com zonas de cisalhamentos Pré-cambrianas do \\ embasamento da Bacia do Paraná, Estado de Santa Catarina, Brasil \\ Patricia Duringer Jacques ${ }^{1,2 *}$, Rômulo Machado², Roberto Gusmão de Oliveira ${ }^{3}$, \\ Francisco José Fonseca Ferreira ${ }^{4}$, Luís Gustavo de Castro ${ }^{4}$, Alexis Rosa Nummer
}

\begin{abstract}
The objective of this article is to characterize the main directions of structures of the Paraná Basin, to define the relation of deep structures (magnetic lineaments) with superficial structures [lineaments obtained over Shuttle Radar Topography Mission (SRTM) images] and analyse reactivated structures in the Phanerozoic. The magnetic lineaments at the Eastern edge of the Paraná Basin, in the central-southern region of the Santa Catarina State, show a main orientation pattern NE-SW and secondarily NNE-SSW. The NE-SW pattern reflects a framework of the ductile structures of the Santa Catarina Shield that continues in the substratum of the basin. The structural NNE pattern appears in the south of the Major Gercino Shear Zone (MGSZ) and the NE pattern appears in the north of this structure. The data obtained shows that the structural NE-SW pattern of the basin, present in the MGSZ and Itajaí-Perimbó Shear Zone as well as in the Tijucas Terrain (Brusque Metamorphic Complex) in Santa Catarina, clearly extends underneath the Gondwanic sequence of the Paraná Basin in the region. Among the products obtained by geophysical data processing in this work, what propitiated the best definition and distinction of the magnetic structures was the tilt angle of the total horizontal gradient (TAHG) method. However, the great flight line spacing of one of the geophysical projects $(7 \mathrm{~km})$ makes the identification of small magnetic structures difficult, particularly in N-S and E-W directions. Such structural directions are referred to in the previous works and were confirmed through the interpretation of SRTM images and studies of brittle structures in the field.
\end{abstract}

KEYWORDS: geophysical; brittle structures; Paraná Basin.

\begin{abstract}
RESUMO: Este artigo tem como objetivo caracterizar as principais estruturas da Bacia do Paraná, definir as relacóes das estruturas mais profundas (alinhamentos magnéticos) com as mais superficiais (lineamentos obtidos por imagens SRTM) e analisar estruturas reativadas no Fanerozoico. A análise de alinhamentos magnetométricos na borda leste da Bacia do Paraná, na porção centro-sul do Estado de Santa Catarina, mostra um padrão principal de direção NE-SW e um padrão secundário NNE-SSW, e referem-se às estruturas presentes no embasamento da bacia. O padrão estrutural NNE localiza-se ao sul da Zona de Cisalhamento Major Gercino e as estruturas $N E$, ao norte. Estes dados evidenciam que o padrão estrutural NE-SW do Escudo Catarinense, presente nas zonas de cisalhamento Major Gercino e Itajai-Perimbó e na Faixa Tijucas (Complexo Metamórfico Brusque), prolonga-se claramente sob as rochas sedimentares e ígneas da Bacia do Paraná. Dentre os produtos obtidos por processamento de dados geofísicos neste trabalho, o que propiciou a melhor definição e realce das estruturas magnéticas foi o TAHG (Tilt Angle of the Total Horizontal Gradient); porém, o grande espaçamento de voo do Projeto Bacia do Paraná (7 km) dificultou a identificação de estruturas de menor dimensão (menor expressão regional), como as estruturas $N-S$ e E-W. Tais direçóes estruturais foram evidenciadas a partir da interpretação das imagens SRTM e de estudos de estruturas rúpteis no campo.
\end{abstract}

PALAVRAS-CHAVE: geofisica; estruturas rúpteis; Bacia do Paraná.

\footnotetext{
${ }^{1}$ Geoprocessing Division, Geologic Survey of Brazil - CPRM, Rio de Janeiro (RJ), Brazil.E-mail: patricia.jacques@cprm.gov.br ${ }^{2}$ Mineral and Hydrogeology Resources Program, Geosciences Institute, Universidade de São Paulo - USP, São Paulo (SP), Brazil. E-mail: rmachado@usp.br ${ }^{3}$ Regional Superintendence of Recife, Geologic Survey of Brazil - CPRM, Recife (PE), Brazil. E-mail: roberto.gusmao@cprm.gov.br

${ }^{4}$ Polytechnic Center, Laboratory for Research in Applied Geophysics, Department of Geology, Universidade Federal do Paraná - UFPR, Curitiba (PR), Brazil. E-mail:francisco.ferreira@ufpr.br; lgcastro7@gmail.com

${ }^{5}$ Universidade Federal Rural do Rio de Janeiro - UFRRJ, Seropédica (RJ), Brazil. E-mail:nummer@ufrrj.br

*Corresponding author

Manuscrito ID 29984. Recebido em: 11/06/2013. Aprovado em: 30/01/2014
} 


\section{INTRODUCTION}

The geophysical methods are indirect investigation techniques that allow the evaluation of geological conditions through the contrast of the physical characteristics of the materials. The analysis of such data provides the delineation of the main structural features, from regional to a more detailed scale, and may allow the delimitation of the different lithotypes, supplying subsidies for the geological cartography (Vasconcellos et al. 1994). The geological-geophysical integration becomes indispensable in the tectonic/structural study of the area (magnetic maps) and in the delimitation of the lithotypes (gamma-ray spectrometric maps), based on the magnetic and radiometric signatures analysis and in the integration with the available geological maps.

The present work has a regional emphasis and comprises the generation of magnetic maps in a scale of 1: 500,000, compatible with the maps of the superficial brittle structures obtained from Shuttle Radar Topography Mission (SRTM) images (Jacques et al. 2010). Some examples of the studies in which magnetic images are used in the identification of structural lineaments are: Gunn et al. (1997); Bournas et al. (2003); Portela Filho et al. (2005); Carneiro et al. (2006);
Medeiros et al. (2011), among others. The present study intends to accomplish the characterization of structures in the eastern edge of the Paraná Basin in Santa Catarina (Brazil) by interpretation of magnetic lineaments and to compare them with the structural analysis of the field data. The specific objectives distinguished are to: (1) characterize the main directions of structures of the Paraná Basin in the study area; (2) define the relation of the magnetic lineaments (deep structures) with features obtained through images of remote sensing in a 1:500,000 scale (superficial structures); and (3) verify the reactivated structures in the basin that affected the sedimentary rocks of the Paraná Basin.

\section{CHARACTERIZATION OF THE STUDY AREA}

The study area (Fig. 1) is located in the central-southern part of the Santa Catarina State in Brazil. It encloses metamorphic rocks of Santa Catarina Shield, and sedimentary and igneous rocks of the Paraná Basin, which are inserted in the tectonic provinces of Mantiqueira and Paraná (Almeida et al. 1977, 1981).

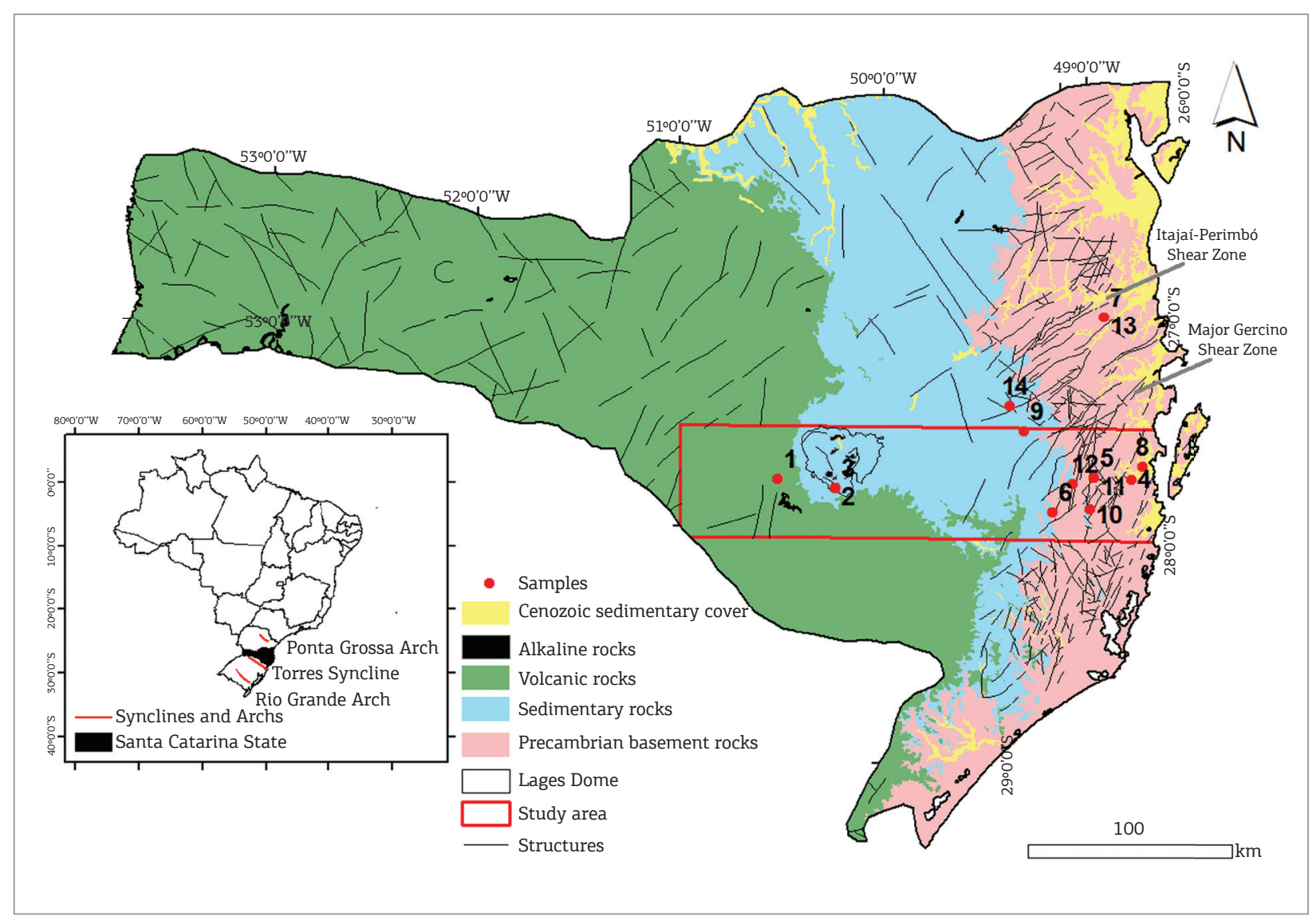

Figure 1. Main geological rocks of Santa Catarina State indicating the study area and the studied outcrops in the regions of the Paraná Basin and the Santa Catarina Shield. 
The Mantiqueira Province comprises Precambrian and Early Paleozoic rocks, displayed in the eastern part of the South American Platform, with an approximate 3,000 km of extension from southern and southeastern Brazilian coast to Uruguay. This province encompasses a Neoproterozoic mobile belt, divided into four diachronic orogens (Araçuaí, Ribeira, Dom Feliciano and São Gabriel), and a zone of interference between the Ribeira and Brasilia orogens (Heilbron et al. 2004). The diachrony of the orogens is evidenced by the oldest ages in the south (São Gabriel Orogen) and more recent ones in the north (Araçuaí Orogen) (Silva 2006). In accordance with Hasui (2010), the Orogenic Mantiqueira System had its final agglutination around 500 to $460 \mathrm{Ma}$. The main structures, in general, are related to NE-SW dextral shear zones (Heilbron et al. 2004).

In Santa Catarina State, the "Dom Feliciano Belt", defined by Fragoso-Cesar (1980), is divided by Basei (2000) in three crustal segments (from SE to NW): Granite Belt (Florianópolis Batholith), Metavolcanosedimentary Belt or Schist Belt (Brusque Metamorphic Complex) and foreland basin (Itajaí Basin). This belt is interpreted as the result of successive subduction and collisions of different blocks, with a maximum interval from $900 \mathrm{Ma}$ (opening of the Adamastor Ocean) to $530 \mathrm{Ma}$ (deformation of the foreland basin) (Babinski et al. 1997; Basei et al. 2005, 2010).

The Brusque Metamorphic Complex, located in the Tijucas Terrain (Fig. 2), has an extension of approximately $75 \mathrm{~km}$ and a maximum width of $45 \mathrm{~km}$. The main direction of these rocks is near NE-SW and they have tectonic limits in the northwest with the Itajaí-Perimbó Shear Zone (Silva 1991) and in the southeast with the Major Gercino Shear Zone (MGSZ) (Bitencourt et al. 1989). Both structures were submitted to ductile deformation in a dextral transcurrent system (Philipp et al. 2004).

The MGSZ has an average width of $20 \mathrm{~km}$ and separates two distinct geological regions: the Florianópolis Batholith in the south and the Brusque Metamorphic Complex (Tijucas Terrain) in the north (Fig. 1). The MGSZ developed on granulite and metavolcanosedimentary rocks, with generation of mylonites, ultra-mylonites and phylonites (Bitencourt et al. 1989). This structure represents an important crustal discontinuity of the Dom Feliciano Belt in the south of Brazil that was active in the final stages of the Brazilian Orogeny (post-collisional), whose deformation occurred in brittleductile system (Bitencourt et al. 1989). Passareli and Basei (1995) studied C-axis of quartz in mylonites and concluded that although the crystallographic orientation indicates environments of relatively low temperatures, the high volume of deformation and the presence of water in the system contributed to the increase in ductility conditions. The tectonic activity of this structure was important to control the
Neoproterozoic granite magmatism of the Santa Catarina Shield (Bitencourt 1996). Several authors have postulated the prolongation of the MGSZ towards the south of Brazil and its connection with the Sierra Ballena Shear Zone in Uruguay (Machado \& Endo 1993; Basei et al. 2005).

The Paraná Basin, with an area of approximately $1,750,000 \mathrm{~km}^{2}$, is one of the great Brazilian tectonic provinces, the sediments of which were deposited on the South American Platform after the stabilization of the Brazilian Orogenic Cycle in the Early Cambrian (Telluric Orogen), when the last cratonic blocks collided were Arequipa-Antofalla (Almeida 1981; Assine 1996). Although the current limits of the basin are erosive, its configuration would have always been influenced by great structures, arches, flexures of the basin and lineaments at its edges, with some of them being evident and others suggestive (Almeida 1981) (Fig. 2).

The different periods of subsidence of the Paraná Basin were correlated with the orogenic events that occurred in the southwestern part of Gondwana, particularly in the region that nowadays corresponds to the Andean edge of South America that practically represented a region of convergence between the sialic block and the oceanic lithosphere of Panthalassa during the whole Phanerozoic. These orogenic events are called in literature as Ocloyca (Meso to Neo-Ordovician), Precordillerian (Predevonian), Chanica (Precarboniferous) and Sanrafaelica (Neopermian) (Assine 1996; Milani \& Ramos 1998).

There are certain authors who do not share the above interpretation and consider that the reiterated tectonic mobility of the Andean chain had very few consequences on the structure and stratigraphy of the basin, at least in Brazil (Almeida 1981). Certain other authors, however, consider that the peaks of tectonic activities in the Andean region developed the subsidence and resulted in great transgressions, with the accumulation of thick and extensive packages of sandstones in the Paleozoic sedimentary succession of the Paraná Basin and the development of regional variances (Zalán et al. 1991; Assine 1996).

The Paraná Basin has been classified as a syneclise type; however, there are no well-established theoretical models that can adequately explain the repetitive subsidence of extensive areas in the interior parts of the continents over a period of hundreds of millions of years (Milani 2004). There are certain authors who consider the existence of initial NW-SE-oriented features (Fulfaro et al. 1982), whereas certain others propose, on the basis of geophysical information and the isopach shape (Northfleet et al. 1969; Quintas 1995), a control of the NE-SW structures in the tectonic sedimentary evolution of the basin, mainly the Paleozoic, only modified by the rupture of the Gondwana and opening of the South Atlantic (Zalán et al. 1991). 
The NE structures, present in the substract of the Paraná Basin and located at its immediate edges or in its interior part (Almeida 1981), would have controlled the development of a "central rift" in the basin with NE-SW direction, coincident with the axis of the drainage basin of the Paraná River, whose presence is suggested through

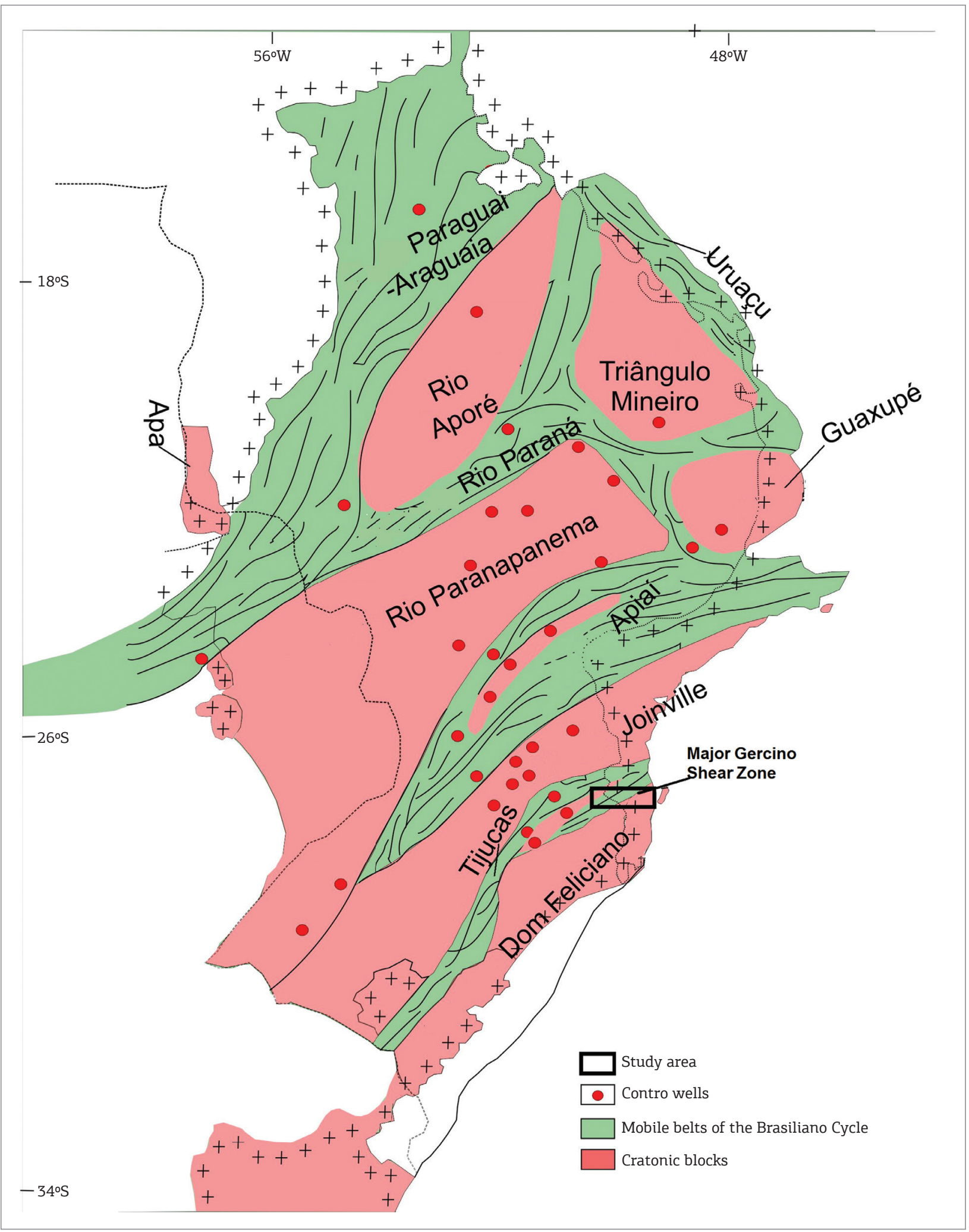

Figure 2. Tectonic structure of the Paraná Basin substract with highlight on the study area (modified by Milani 1997). 
geophysical data (gravimetric, magnetometric and reflection seismic) and by the information of deep stratigraphic wells (Milani 2004). The anomalies in the Bouguer map in the basin show a highly gravimetric extension, limited by high gravimetrical gradients, suggesting the presence of a block interposed among other types of structures in the central part of the basin (Quintas 1995).

\section{Structural frame}

Three main directions in the structural frame of the basin are identified: $\mathrm{N} 45^{\circ}-65^{\circ} \mathrm{W}, \mathrm{N} 50^{\circ}-70^{\circ} \mathrm{E}$ and $\mathrm{E}-\mathrm{W}$, with the $\mathrm{NW}$ and NE directions being the oldest ones, originating from the reactivation of weakness zones present in the basement of the basin (Zalán et al. 1991). The E-W lineaments and the NW faults were developed from the Triassic, during the separation of the Gondwana, whereas the NE structures would have remained inactive (Zalán et al. 1987).

Based on Landsat and radar images in the 1:250,000 scale, encompassing areas of the Serra Geral Formation in the southeast of Brazil (São Paulo, Paraná, west of Santa Catarina and north of Rio Grande do Sul), Soares et al. (1982) highlight six directions of lineaments (in decreasing frequency sequence) which show the following regional trend: (i) $\mathrm{N} 45^{\circ}$ $\pm 5^{\circ} \mathrm{W}$ Médio Ivaí (30\%); (ii) N65 $\pm 5^{\circ} \mathrm{W}$ Médio Piquiri (22\%); (iii) N25 $\pm 5^{\circ} \mathrm{W}$ Goioxim (19\%); (iv) N35 $\pm 5^{\circ} \mathrm{E}$ Médio Paraná (19\%); (v) N05 $\pm 5^{\circ}$ E Tapiracuí (8\%); and (vi) $\mathrm{N} 60^{\circ} \pm 5^{\circ} \mathrm{E}$ Pitanga (6\%). Five of these directions of lineaments were characterized in the sedimentary layers (i, ii, iii, iv and vi), with Médio Piquiri $\left(\mathrm{N} 65^{\circ} \pm 5^{\circ} \mathrm{W}\right)$ being the most frequent $(19.1 \%)$ and Pitanga $\left(\mathrm{N} 60^{\circ} \pm 5^{\circ} \mathrm{E}\right)$ being the less frequent $(9.4 \%)$.

An integrated multiscale analysis (structural, satellite images, gravimetry and magnetometry), applied at the eastern edge of the Paraná Basin, encompassing the neighbouring regions of the Santa Catarina and Paraná states, showed the existence of five main lineament directions: $\mathrm{N} 60^{\circ}-70^{\circ} \mathrm{E}, \mathrm{N} 30^{\circ}-40^{\circ} \mathrm{E}, \mathrm{NNE}, \mathrm{NNW}$ and NW (Freitas \& Rostirolla 2005).

Based on the interpretation of digital products, studies of the structural lineaments in the Dome of Lages, highlighted five main directions: WNW, N-S, NNE, ENE and NW (Roldan 2007; Roldan et al. 2010). Some of these directions were characterized as transcurrent faults: dextral N-S, NNE and NE, and sinistral WNW and E-W. These two main fault systems affect the alkaline rocks (Roldan 2007) whose age can be placed around $75 \mathrm{Ma}$ (Scheibe et al. 1985; Machado \& Teixeira 2008). Machado et al. (2012), who presented the structural analysis of alkaline rock quarries, associated with the Dome of Lages and identified two main directions of brittle structures related to the tectonic development: one around N-S (NNW to NNE), with dextral kinematics, and another one close to E-W (ENE to ESE), with sinistral kinematics. Such structures, ages of which are related to Eocretaceous to Tertiary periods, were explained according to a compressive event with a maximum principal stress axis $\left(\sigma_{1}\right)$ oriented around NE-SW.

\section{MATERIALS AND METHODS}

The aerogeophysical covering of the study area is composed of the Serra do Mar Sul, Ponta Grossa-Criciúma (Area 1) and Bacia do Paraná projects, which integrate the Brazil Geophysical Projects Database from CPRM (Geological Survey of Brazil). The specifications and the index map of the surveys are presented in Tab. 1 and in Fig. 3, respectively.

The magnetic data were submitted to the micro-levelling routines aiming for the extraction of high-frequency signals (noises) deriving from levelling process problems. The contribution of the IGRF (International Geomagnetic Reference Field) corresponding with the acquisition date of each survey was subtracted from the micro-levelled data, resulting in the magnetic field anomaly maps that were integrated in a unique data set.

For the construction of the unified aeromagnetic database, the Serra do Mar Sul and Ponta Grossa-Criciúma (Area 1) surveys were continued upwards to flying height of the Bacia do Paraná project $(1,500 \mathrm{~m})$ (Tab. 1, Fig. 3). The data of the three projects were interpolated by the Minimum Curvature method (Briggs 1974), with a grid of one-sixth of average spacing, generating a $500 \times 500 \mathrm{~m}$ regular grid.

The results (Fig. $4 \mathrm{~A}$ ) of this procedure were integrated by applying the suture routine of the GridKnit module on the

Table 1. Specifications of the aerogeophysical surveys in the study area

\begin{tabular}{l|c|c|c|c|c|c|c}
\hline $\begin{array}{l}\text { CPRM } \\
\text { Code }\end{array}$ & Contractor & Project & Year & Line spacing $(\mathbf{m})$ & $\begin{array}{c}\text { Flying height } \\
(\mathbf{m})\end{array}$ & $\begin{array}{c}\text { Sampling } \\
\text { interval }(\mathbf{m})\end{array}$ & Total (km) \\
\hline 1025 & CPRM & Serra do Mar Sul & 1975 & 1,000 & 150 & 60 & 49,880 \\
\hline 2010 & NUCLEBRAS & $\begin{array}{c}\text { Ponta Grossa }- \\
\text { Criciúma (Área I) }\end{array}$ & 1971 & 1,000 & 120 & 120 & 33,810 \\
\hline 4012 & PETROBRAS & Bacia do Paraná & 1973 & 7,000 & 1,500 & 70 & 20,650 \\
\hline & & & & & & Total & 104,340 \\
\hline
\end{tabular}


Oasis Montaj software (Geosoft 2010), in which the datasets are joined by a line defined based on the overlapping projects. The incompatibilities between the data along this line are adjusted by the average values of matched pairs, providing a smooth fit between the grids. This routine procedure applies a multifrequency approach, which distributes the correction in data sets involved as a function of the wavelength of the incompatibilities found along the suture line. This procedure provides a smooth transition between the data sets (Geosoft 2010).

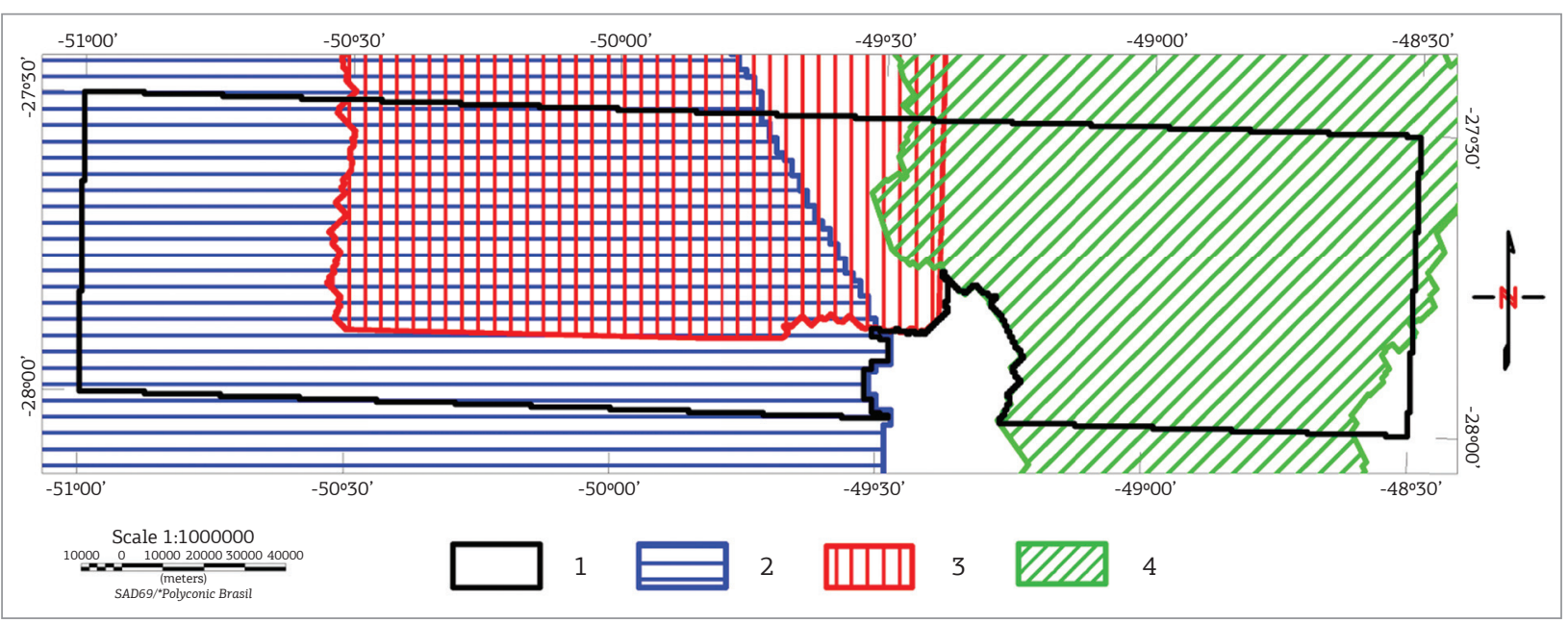

Figure 3. Index map of the aeromagnetic covering of the study area. (1) Study area, (2) Bacia do Paraná Project, (3) Ponta Grossa-Criciúma (Area I) Project and (4) Serra do Mar Sul Project.

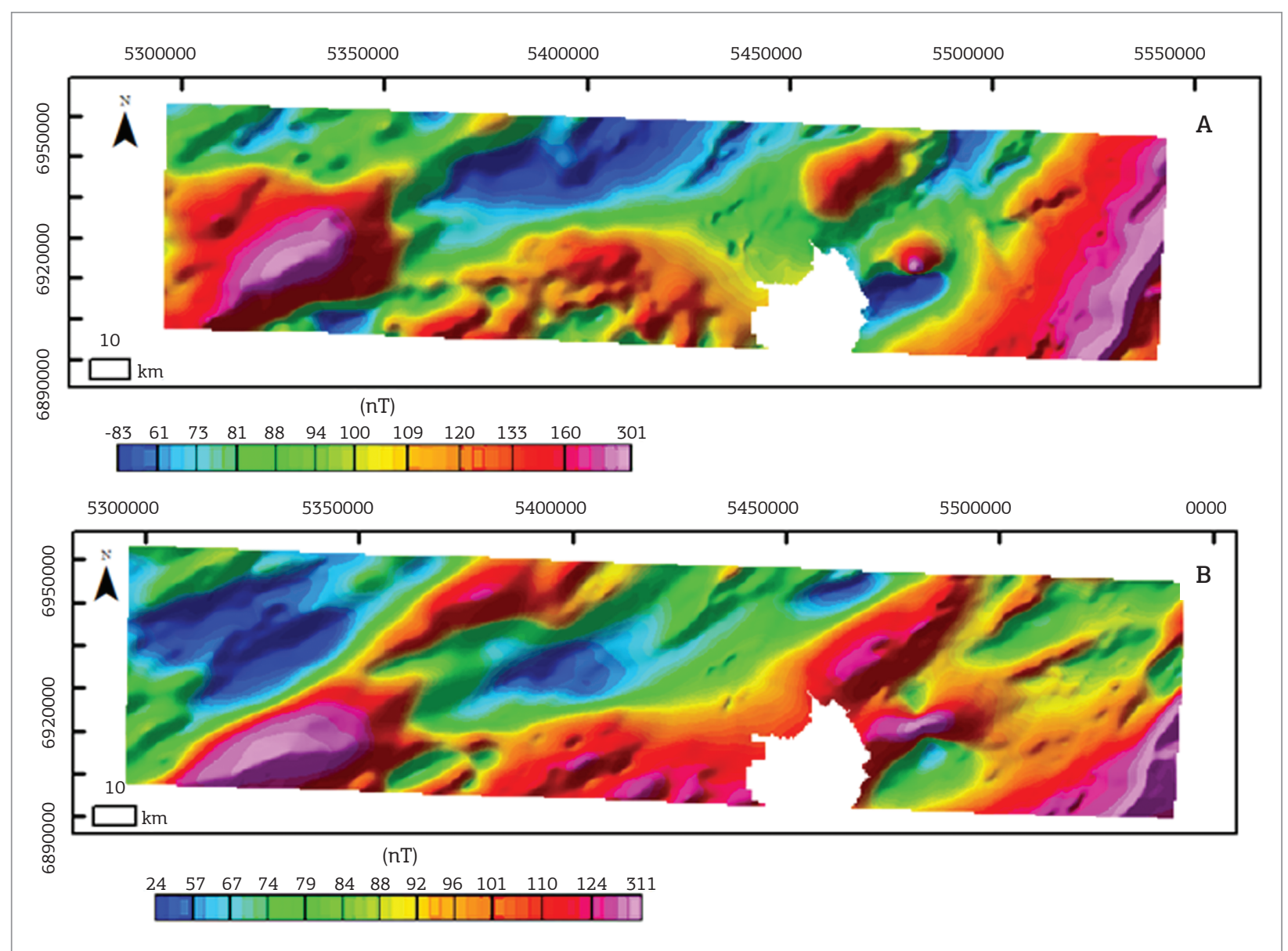

Figure 4. (A) Magnetic field anomaly map. (B) RTP magnetic field anomaly map. 
On these data, the following enhancement methods were applied:

Reduction to the Pole (RTP) (Fig. 4B): This was used to recalculate the data of the magnetic field anomaly map at an inclination of $90^{\circ}$ (magnetic pole of the Earth). The RTP simulates the localization of the magnetic source at the magnetic pole in a mode that its centre coincides with the maximum positive amplitude of the anomaly. This procedure facilitates the interpretation of the data. An average date between the surveys (20 March 1976) was used for the attainment of the RTP, which results in the values of $-13^{\circ} 59^{\prime}$ of declination and $-29^{\circ} 27^{\prime}$ of inclination.

- Total Horizontal Derivative (THDR) (Cordell \& Grauch 1985): This was used to accentuate the abrupt lateral changes of physical properties, enhancing the limits of the causative bodies. The THDR is the resulting vector of the combinations of the first horizontal derivatives in $x$ and $y$ directions (Fig. 5).

- Analytical Signal Amplitude (ASA) (Nabighian 1972; Roest et al. 1992): The ASA is a function related to the derivatives of the magnetic field in $x, y$ and $z$ directions (Fig. 5). The ASA is often considered a method that is not affected by magnetic inclination; however, this has been contested so by $\mathrm{Li}$ (2006).

- Tilt Angle (TDR) (Miller \& Singh 1994): The tilt angle is defined by the arctangent of the first vertical derivative divided by the THDR (Fig. 5). This filter equalizes the signal amplitudes and the peaks of the transformed data are positioned over the centre of the causative body instead of the edges. Consequently, the tilt angle responds well both to shallow and deep sources.

- TDR_THDR: Verduzco et al. (2004) applied THDR of the TDR to enhance the edges of the bodies through maximum (Fig. 5). The advantages of this method are, according to the authors, the independence of the magnetization direction and the amplitude of the anomalies.

- Tilt angle of the total horizontal gradient (TAHG): The main attributes of the TAHG method (Fig. 5) are to provide maximal amplitudes on the source edges and equalizes signals from shallow and deep sources (Ferreira et al. 2010; Ferreira et al. 2013).

Radar images derived from the Digital Elevation Model (DEM) from the Shuttle Radar Topography Mission (SRTM; Farr et al. 2007) were processed and prepared for the manual extraction of brittle lineaments in the scales of 1:500,000

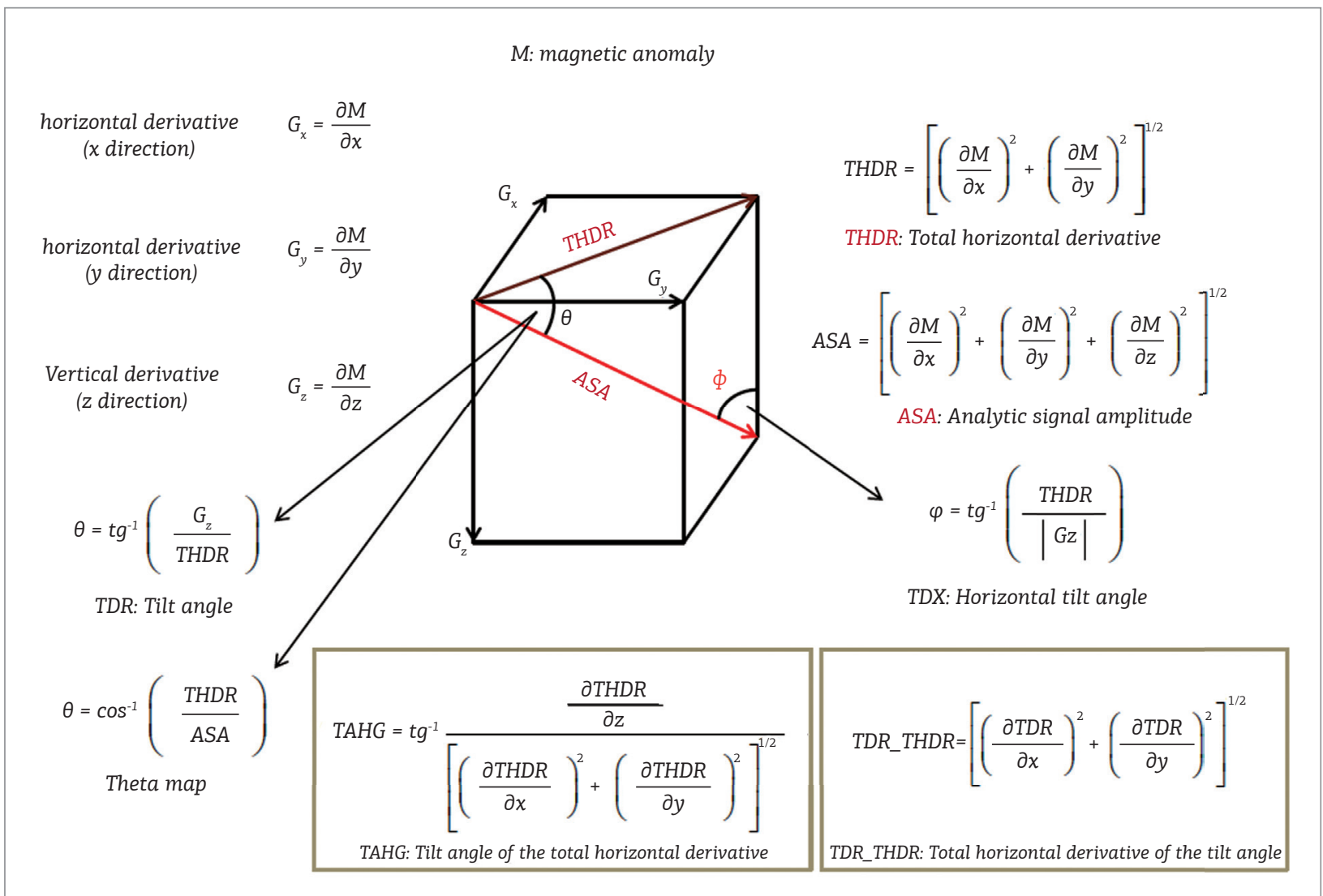

Figure 5. Main methods used for enhancing magnetic anomalies (modified from Ferreira et al. 2010). 
and 1:100,000 (Jacques et al. 2010, 2012). The lineaments of the 1:500,000 scale were compared with the magnetic alignments through the elaboration of main direction cluster maps. The Euclidean distance was used for each set of lineaments (SRTM and magnetic) with the function of three main directions presenting both types of data (NS, NE-SW and NW-SE); thus, the intervals were grouped into three range direction classes: N-S $\left( \pm 30^{\circ}\right)$, NE-SW $\left(31^{\circ}-90^{\circ}\right)$ and NW-SE $\left(270^{\circ}-329^{\circ}\right)$.

The studies in the field are based on the data collection from brittle structures in 14 quarries (nine located in the Santa Catarina Shield, one at the border of the Paraná Basin and the Santa Catarina Shield, two in the basalts of the Serra Geral Formation and two on the sedimentary rocks of the Paraná Basin; Fig. 1). After the data collection, the dihedral method (Angelier and Melcher 1977) was applied to determine the compressive fields (maximum stress) and tractive fields (minimum stress), corresponding, respectively, to the stress axes $\sigma_{1}$ and $\sigma_{3}$. The geometric and kinematic analyses were made for the general outcrops and for the main directions systems: $\mathrm{NNE}\left(0^{\circ}-29^{\circ}\right)$, $\mathrm{NE}\left(30^{\circ}-59^{\circ}\right)$, ENE $\left(60^{\circ}-89^{\circ}\right)$, WNW $\left(90^{\circ}-119^{\circ}\right)$, NW $\left(120^{\circ}-149^{\circ}\right)$ and NNW $\left(150^{\circ}-179^{\circ}\right)$.

\section{RESULTS}

The interpretation of the lineaments in the enhanced magnetic maps allowed identification of the features that support the understanding of the structural frame at the eastern edge of the Paraná Basin in Santa Catarina State. The visual analysis of the aeromagnetic maps enhanced by the filtering techniques presented in Figs. 6A to 6D allowed the interpretation of the magnetic lineaments presented in Fig. 6E. The TAHG map was the main product used for the interpretation of the magnetic lineaments (Fig. 6E). This map enhance the shallower sources and shows the structural framework of the study area with emphasis on the NE lineaments, probably related to the continuity of the Tijucas Terrain (Brusque Group) structures under the sedimentary and igneous rocks of the Paraná Basin (Fig. 2). Those lineaments are more pronounced in the central and western portion of the studied area, where sedimentary and igneous rocks of the Paraná Basin occur. The analysis of the rose diagrams of the magnetic lineaments (Fig. 7) shows the approximately uniform behavior of the structural NE trend, whereas the field data disclose other structural directions not evidenced in the products obtained by the processing of the aeromagnetic data (Fig. 8).

The NE direction is identified in the outcrops of the Serra Geral Formation and the Santa Catarina Shield regions.
The Santa Catarina Shield secondarily enhances NS and NW lineaments. Directions close to N-S are also highlighted on the sedimentary rocks at the field, although the data are derived from only two outcrops. In the outcrops of the Serra Geral Formation, the presence of E-W structures was observed. The E-W lineaments were not identified in the interpretation of the magnetic data (only locally in the region of the Serra Geral Formation). This may be related to the great spacing between the flight lines used in the aerogeophysical surveys (varying from 1,000 to 7,000 m) making the identification of structures of lesser dimensions difficult, and probably those are not being related to the basement structures. In accordance with Zalán et al. (1987), the E-W lineaments developed during the Gondwana separation is therefore being active as the lineaments developed from the Triassic.

The NW structures are well marked in the aeromagnetic maps of the Ponta Grossa Arch region (Guapiara, São Jerônimo-Curiúva, Rio Alonso and Rio Piquiri lineaments) and extend at least till the current channel of the Paraná River considered as being the deep structures that reached the upper mantle (Ferreira 1982). Those structures correspond to the lineaments with a direction of higher frequency (30\%), referred as Médio Ivaí (Soares et al. 1982). NW extensional faults are recognized in Ponta Grossa Arch, which were reactivated as sinistral faults and are explained according to a tectonic context of two distinct deformational events: an older one ( $\sigma 1-\mathrm{I}$ or D1) of Precretaceous age and a newer one ( $\sigma 1-\mathrm{II}$ or D2) aged between Precretaceous and Tertiary (Rostirolla et al. 2000; Strugale 2002; Strugale et al. 2007).

The magnetic total field anomaly shown in Fig. 5 represents the sum of a series of anomalies caused by shallow and deep sources. The separation of the effect of these sources requires assumptions and the use of a series of transformations on the data for the process of interpretation and geological correlation. Statistical depths from the top of magnetic sources were estimated using the method developed by Spector and Grant (1970). When considering a grid that is large enough to include many sources, the $\log$ spectrum of these data can be interpreted to determine the statistical depth to the top of the sources. The depth of an ensemble of sources is easily determined by measuring the slope of the energy power spectrum and dividing it by $4 \pi$. The analysis of the radially averaged power spectrum of the magnetic total field anomaly data used in this study allowed the identification of least four main sets of magnetic sources (Fig. 9). Possibly the most shallow sources $(<3 \mathrm{~km})$ are located in the exposed basement of the basin. The deeper sources must $(>3 \mathrm{~km}$ ) correspond to the sources covered by the sediments of the basin.

Cluster images representing directions NS, NW and NE are shown in Fig. 10A (magnetic lineaments) 

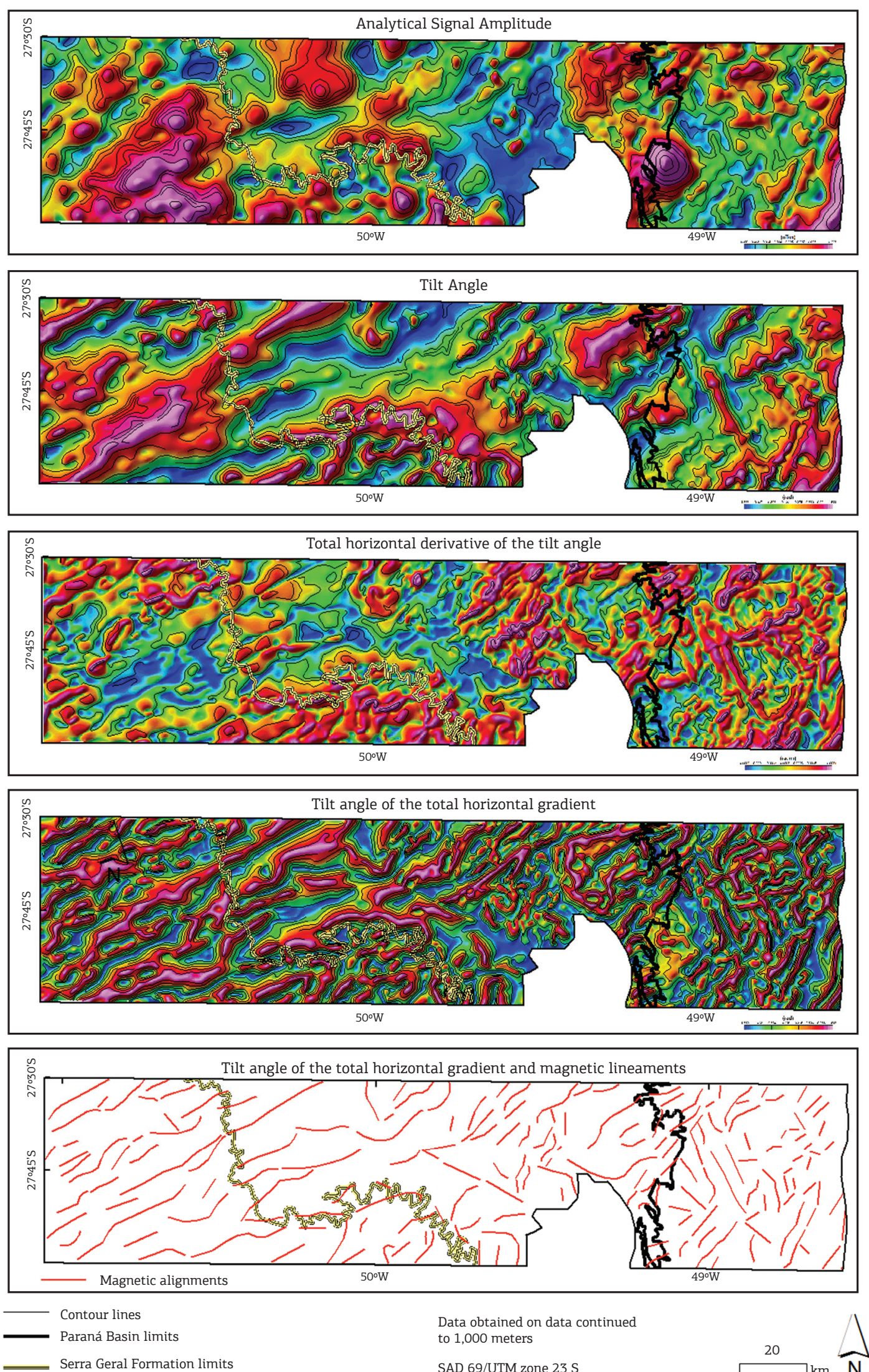

$$
\begin{aligned}
& \text { Data obtained on data continued } \\
& \text { to 1,000 meters } \\
& \text { SAD 69/UTM zone } 23 \mathrm{~S}
\end{aligned}
$$

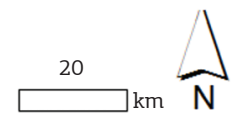

Figure 6. Enhanced magnetic maps of the study area. 
and 10B (SRTM lineaments). Figure 10C presents two classes: one with the regions of the same cluster (directions NS, NW or NE) and another with the regions of different clusters. The coinciding data among the clusters of the directions in the entire study area amount to $35 \%$, whereas the differences amount to $65 \%$. The coincidences and differences were also applied by rock region: the Santa Catarina Shield, Paleozoic rocks of the Paraná Basin and the Serra Geral Formation (Fig. 10D). The biggest coincidences occur in the regions of the Serra Geral Formation and the Santa Catarina Shield, with very close values.

Figure 8 presents the rose diagrams of the studied outcrops, where three main directions (NE, NW and NS) of brittle structures stand out for the sedimentary rocks and the Santa Catarina Shield, with the first two directions presenting secondary importance in those regions. Figure 8 also presents the directions NE and close to E-W for the rocks of the Serra Geral Formation. It is important to emphasize that in one of the analysed outcrops at the border of the Santa Catarina Shield with the Paraná Basin, an oblique NE-SW direction fault with high angle dip was identified that only affects the orthogneisses of the basement. This fault developed under brittle-ductile conditions and the deformation in transtensional system occurred with a compression axis oriented in NW-SE direction (Fig. 11).

\section{DISCUSSION}

Structures close to N-S are concentrated in the Santa Catarina Shield, occurring mainly in the south of the MGSZ. They were studied by Castro et al. (2003) based on Landsat-5/TM images and aerogeophysical maps (gamma-ray spectrometric and magnetic), in an area between the Itajaí-Perimbó Shear Zone and MGSZ. According to the authors, those structures were also registered in the sedimentary rocks of the Paraná Basin and confirmed by field data obtained in that work. These structures were also identified in the Dome of Lages region, cutting the alkaline rocks considered to be of Post-Cretaceous ages (Roldan 2007; Roldan et al. 2010; Machado et al. 2012).

The N-S structures of the Santa Catarina Shield have the same orientation of the characterized lineaments as the Tapiracuí direction ( $\left.5^{\circ} \pm 5^{\circ} \mathrm{W}\right)$ (Soares et al. 1982) that has one of the lowest frequencies $(8 \%)$ among the

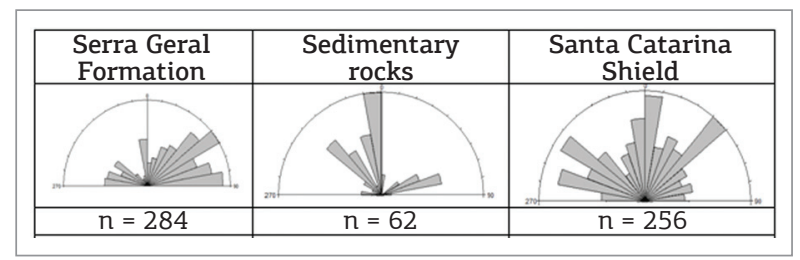

Figure 8. Rose diagrams of the structural field data. Left to right: Serra Geral Formation, Sedimentary Rocks of the Paraná Basin and the Santa Catarina Shield.

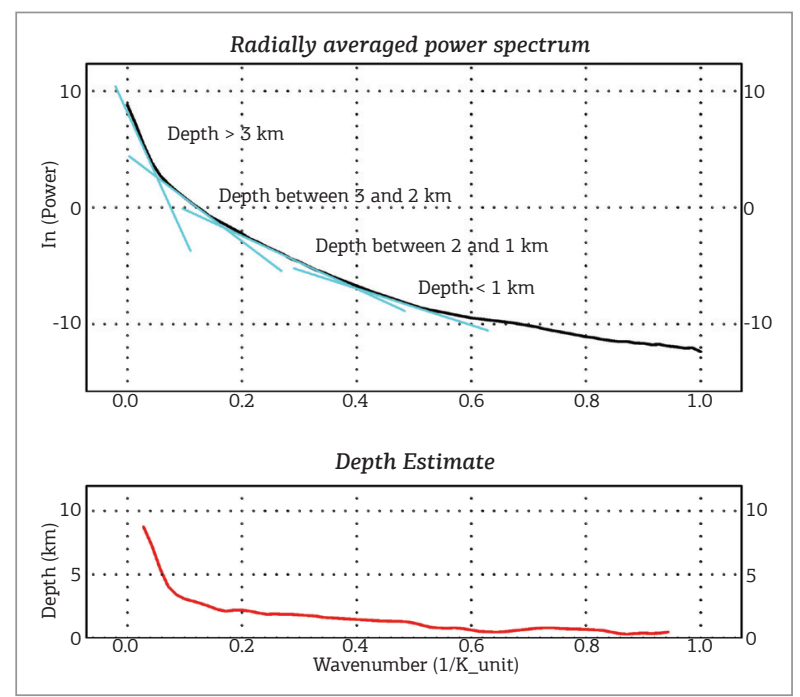

Figure 9. Radially averaged power spectrum of the magnetic total field anomaly.

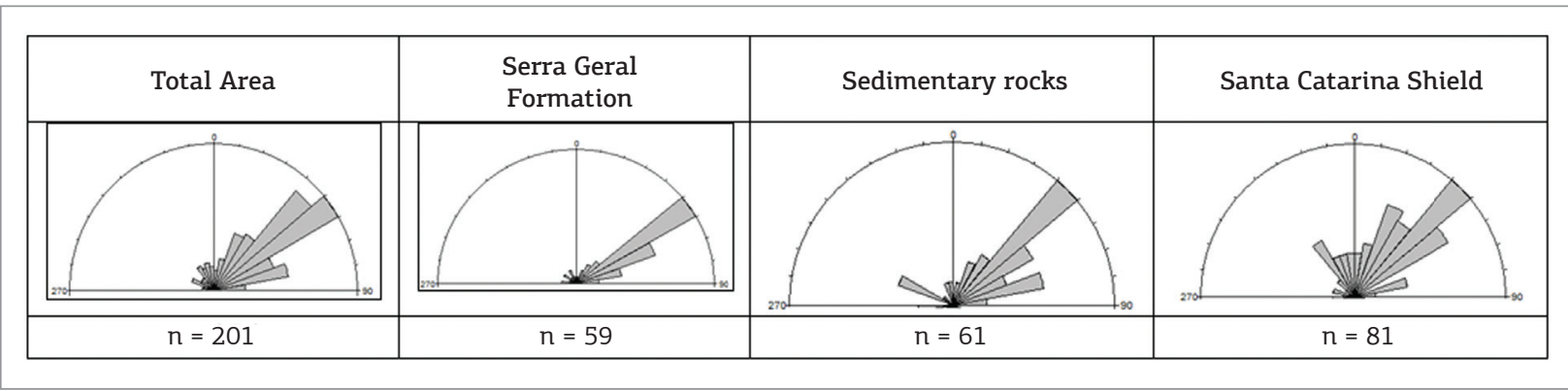

Figure 7. Rose diagrams of the magnetic lineaments. Left to right: total study area, Serra Geral Formation, Paleozoic rocks of the Paraná Basin and rocks of the Santa Catarina Shield. 
six directions defined by the authors. It is therefore considered a lineament of restricted occurrence whose age was related to a deformational event after Caiuá (Eocretaceous) (Soares et al. 1982). The structural N-S pattern presents influence on the sedimentary deposition of the Furnas Formation, being replaced by the NW and NNW structures during deposition of the Ponta Grossa Formation, at which time the basin was divided into two sub-basins, a condition that persists during the deposition of the Itararé Group and the Aquidauana Formation, despite the remarkable inversion that occurred along the fault zone Curitiba-Maringa (Zalán et al. 1990). The structural NE pattern started to have a strong influence on the deposition of the Rio Bonito Formation, evidenced in the isopach lines along the fault zone Lancinha-Cubatão.

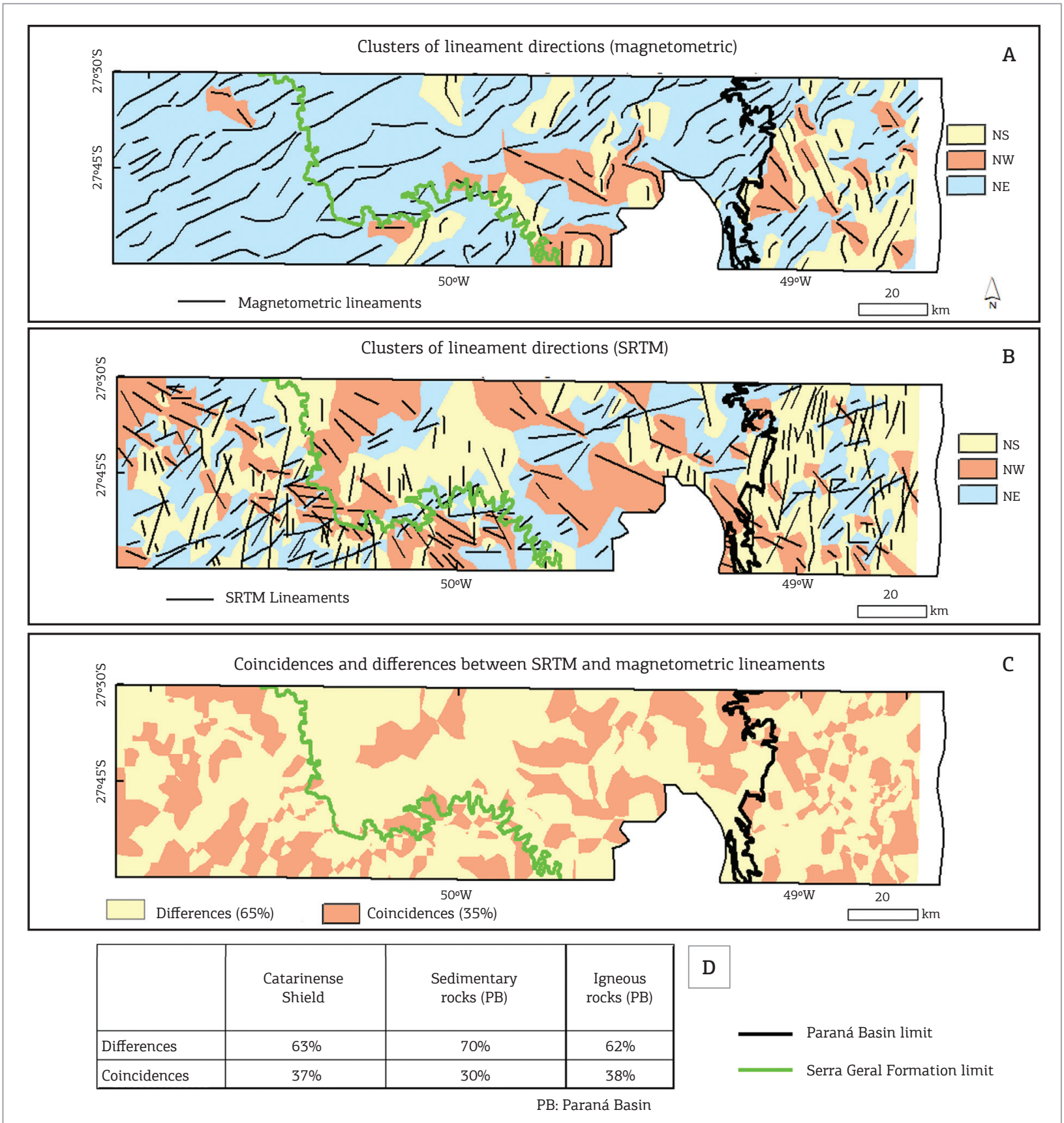

Figure 10. Cluster images of the directions NS, NW and NE, obtained by Euclidean distance. (A) Magnetic lineaments; (B) SRTM lineaments (Jacques et al. 2010); (C) map of the differences and coincidences between the directional clusters; and (D) table showing the percentages of the differences and coincidences for the rock groups of the studied regions. 


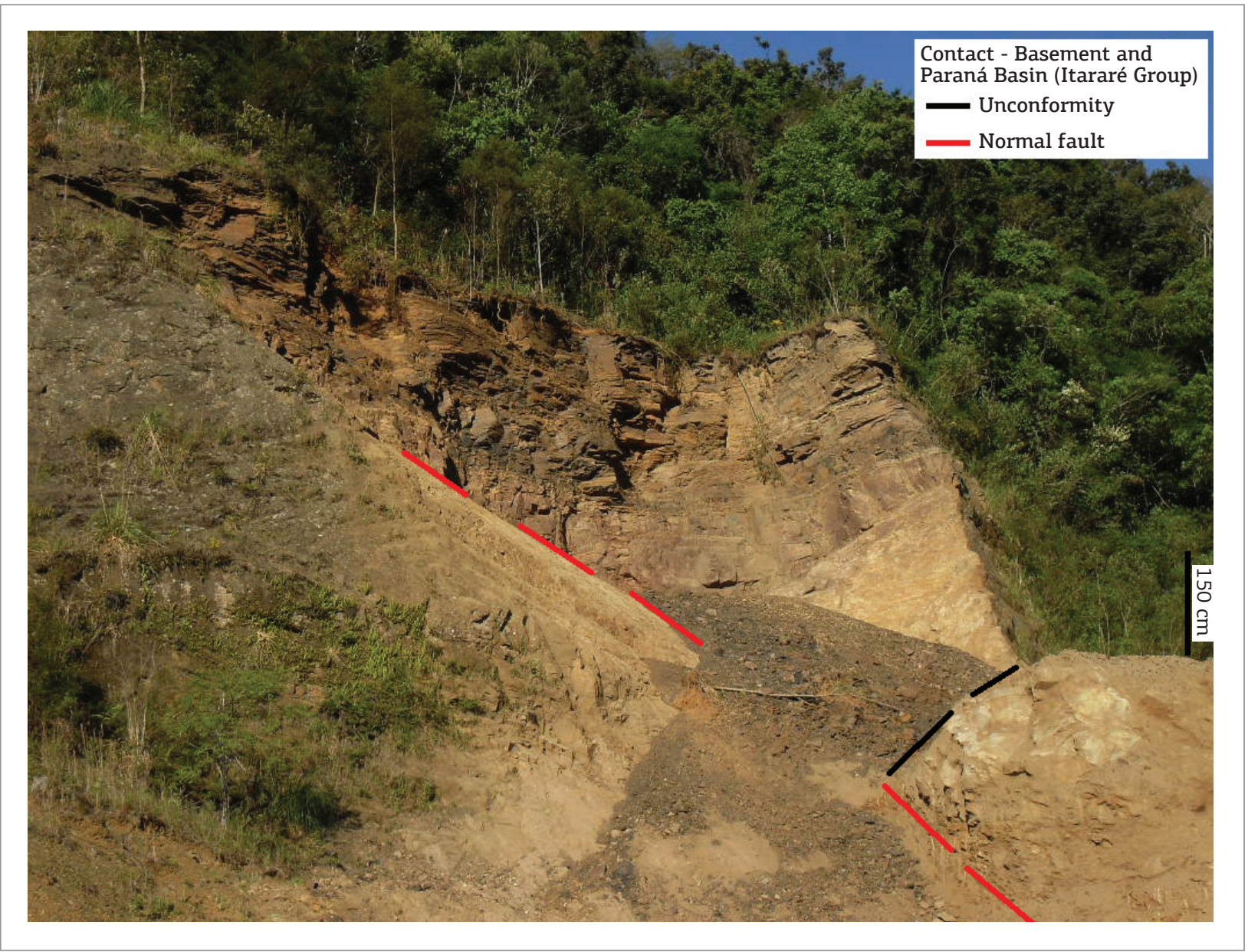

Figure 11. Tectonic contact of the Paraná Basin (Itararé group) with the basement.

The NE-SW structures separates two distinct structural trends: one in NE, situated at the north of the MGSZ and the other close to N-S, situated at the south of the MGSZ (Basei 2000; Basei et al. 2000; Bitencourt et al. 2008; Jacques et al. 2010, 2012). The MGSZ presents an NNE inflection extending under the sedimentary rocks of the Paraná Basin in the study area, and then returning to NE direction. This anastomosing pattern of the MGSZ is typical of shear zones that are part of the South-Brazilian Shear Belt (Bitencourt et al. 2008), the structures of which range from NE to NNE (Passarelli et al. 2011).

The structural NE-SW and NNE-SSW directions, present in the Precambrian rocks of the Santa Catarina Shield, respectively, in the zones of Major Gercino Shear and Itajaí-Perimbó as well as in the Florianópolis Batholith, were reactivated after the spills of the volcanic rocks of the Serra Geral Formation and its sedimentary coverings, like the Bauru and Caiuá Groups (Soares et al. 1982). At the Dome of Lages, this structural pattern was reactivated clearly after the intrusion of the alkaline rocks (aged ca. $75 \mathrm{Ma}$ ) as transcurrent faults, suggesting that this reactivation occurred between the Late Cretaceous and the Tertiary periods (Roldan 2007; Roldan et al. 2010; Machado et al. 2012). The structural NE-SW direction is compatible with the Pitanga direction and the NNE-SSW direction is compatible with the Médio Paraná direction, both related to the directions described by Soares et al. (1982). The first one presents the lowest frequency $(6 \%)$ and the second one an intermediate frequency $(19 \%)$, in relation to the set of six directions defined by the authors. The NE-SW direction is concentrated in restricted areas and appears with more frequency in the lower layers of the basin, being considered a direction of very old discontinuity, just like the NNE-SSW direction that had great activity in the Cretaceous period (Soares et al. 1982).

The structural NNE pattern had great influence on the tectonic-sedimentary evolution of the basin, notably from the deposition of the Irati, Serra Alta, Teresina and 
Rio do Rastro formations, as the maps of accumulated isopach suggest. This influence becomes more evident when the maps of the related formations are individually analysed (Northfleet et al. 1969).

Among the data related to the tectonic origin of the Paraná Basin stand out those collected in the outcrop of the contact between the Paraná Basin and the basement. It is a brittle - ductile shear zone of NNE direction, developed in extensional regimen, which only affects the orthogneisses of the Santa Catarina Shield and does not spread into the sedimentary units of the Itararé Group, suggesting its correspondence with a structure developed previously to the sedimentation of the sedimentary units of the Paraná Basin in Santa Catarina. This extensional structure must be related to the transtensional tectonics that generated initial rifts in the directions which were close to NE-SW, proposed by Milani (1997), and is also compatible with the magnetic lineaments presented in this article.

The aeromagnetic data were efficient to delineate structural alignments whose depths may be greater than $3 \mathrm{~km}$, mainly those of NE direction related to the structural framework of the basin. The comparison between the magnetic and SRTM lineaments obtained $35 \%$ coincidence, probably reflecting the difference of the nature of the data, as the products obtained from the magnetic data reflect deeper structures than those identified from the SRTM data. Jacques et al. (2010) registered in lineaments obtained from SRTM images, in the 1:500,000 scale, the following main directions: NS $\pm 5^{\circ}$ (Santa Catarina Shield), NW-SE and, secondarily, NE (in the Paleozoic and Mesozoic units of the Paraná Basin). This difference of NE main direction (magnetic data) and NW main direction (SRTM data) for the studied region suggests in the first case the reflection of deeper structures (lineaments), originated in the basement (related to the Tijucas Terrain), whereas in the last case they would be shallower structures related to the deformation of the sedimentary and volcanic units of the Paraná Basin.

Most magnetic alignments were obtained from the TAHG data as they provide maximal amplitudes on the source edges and equalizes signals from shallow and deep sources.

\section{CONCLUSIONS}

TAHG, the best product obtained by geophysical data processing, provides the distinction of the magnetic structures.
Great flight spacing of the Bacia do Paraná project $(7,000 \mathrm{~m})$ did not allow the identification of lesser dimension (lesser regional expression) structures, such as the N-S and E-W structures.

- The NE structures would have controlled the development of a "central rift" of the basin with the NE-SW direction, coinciding with the axes of the drainage basin of the Paraná River.

- Structural NE-SW pattern of the Santa Catarina Shield, present in the MGSZ and Itajaí-Perimbó Shear Zone as well as in the Tijucas Terrain (Brusque Metamorphic Complex), extends clearly under the sedimentary and igneous rocks of the Paraná Basin.

Variation of the NE to NNE directions, mainly present in the eastern part of the study area, can be explained by the anastomosed structures of the basement similar to what occurs in the Major Gercino and Itajaí-Perimbó shear zones.

Lineaments obtained from SRTM images in the scale of 1:500,000 indicate the existence of a large number of NW and N-S direction structures, mainly in the region of the Paleozoic rocks, suggesting that the structures are shallower in this region than those in the Ponta Grossa Arch region. Such structures are probably related to the tectonic deformation of the basin and are located in the region between the related arch and the Torres Syncline.

- Field data does not show relation with magnetic structural directions, such as E-W in the Serra Geral Formation, N-S and NW in the Paleozoic sedimentary rocks, suggesting that these structures are related to the deformation of the basin.

- The presence of extensive shear zones in the basement at the eastern edge of the Paraná Basin in Santa Catarina, developed in a brittle-ductile deformation and without continuity in its sedimentary units, suggests that these structures are related to the transtensional tectonic event that originated the NE-SW precursor rift of the Paraná Basin.

- The main directions of structures presents at the Paraná Basin in the study area are: NE-SW (related to deep structures obtained through aeromagnetic images), NW-SE, N-S and E-W (related to superficial structures obtained by SRTM images or at the field).

The directions identified (NE-SW, NW-SE N-S and E-W) affects the sedimentary rock of the Paraná Basin.

\section{ACKNOWLEDGMENTS}

The authors thank the institutional collaborators represented by the CPRM - Geologic Survey of Brazil; 
by the São Paulo University - Post Graduate Program in Mineral Resources and Hydrogeology; by the Federal University of Paraná (Geology Department) and by the Federal Rural University of Rio de Janeiro (Geosciences Department). The first author thanks CAPES for the concession of a doctorate scholarship, R. Machado and F.J.F. Ferreira thank the National Council for Scientific and Technological Development (CNPq) for the concession of productivity in research grants (processes 300423/82-9 and 305810/2010-3, respectively).

\section{REFERENCES}

Almeida F.F.M. 1981. Síntese sobre a tectônica da Bacia do Paraná. In: SBG, Simp. Reg. Geol., 3, Curitiba, Minutes, v. 1, p. 1-20.

Almeida F.F.M., Hasui Y., Neves B.B.B., Fuck R.A. 1977. Províncias estruturais Brasileiras. In: SBG, Simp. Geol. Nordeste, 8, Campina Grande, Minutes, p. 363-391.

Almeida F.F.M., Hasui Y., Neves B.B.B., Fuck R.A. 1981. Brazilian structural provinces: An introduction. Earth Science Reviews, 17(1/2):1-29.

Angelier J. \& Melcher P. 1977. Sur une méthode graphique de recherché dês constraints principales également utilizable en tectonique et en séismologie: La méthode dês dièdres droits. Bulletin de la Société Géologique de France, 7:1309-1318.

Assine M.L. 1996. Correlação entre as sequências précarboníferas da Bacia do Paraná e as orogenias pré-andinas. In: SBG, Congr. Bras. Geol., 34, Salvador, Annals, v. 5, p. 399-401.

Babinski M., Chemale F., Hartmann L.A., Van Schmus W.R., Silva L.C. 1997. U-Pb and Sm-Nd geochronology of the Neoproterozoic granitic-gneissic Dom Feliciano Belt, Southern Brazil. Journal of South American Earth Sciences, 10:263-274.

Basei M.A.S. 2000. Geologia e Modelagem Geotectônica dos Terrenos Pré-cambrianos das Regiões Sul-oriental Brasileira e Uruguaia: Possíveis Correlações com Províncias Similares do Sudoeste Africano...Africano. Post-doctoral Dissertation, Instituto de Geociências, Universidade de São Paulo, São Paulo, $124 \mathrm{p}$.

Basei M.A.S., Brito Neves B.B., Siga Jr. O., Babinski M., Pimentel M.M., Tassinari C.C.G., Hollanda M.H.B., Nutman A., Cordani U.G. 2010. Contribution of SHRIMP U-Pb zircon geochronology to unravelling the evolution of Brazilian Neoproterozoic fold belts. Precambrian Research, 183:112-144

Basei M.A.S., Frimmel H.E., Nutman A.P., Preciozzi F., Jacob J. 2005. The connection between the Neoproterozoic Dom Feliciano (Brazil/Uruguay) and Gariep (Namibia/South Africa) orogenic belts. Precambrian Research, 139:139-221.

Basei M.A.S., Siga Jr. O., Masquelin H., Harara O.M., Reis Neto J.M., Preciozzi P.F. 2000. The Dom Feliciano Belt and Rio de la Plata Craton: Tectonic evolution and correlation with similar provinces of southwestern Africa. In: U.G. Cordani, E.J. Milani, A. Thomas Filho, D.A. Campos (eds.), Intern. Geol. Congr., Rio de Janeiro. Tectonic Evolution of South America, 31:311-334.

Bitencourt M.F. 1996. Granitoides Sintectônicos da Região de Porto Belo, SC: Uma Abordagem Petrológica e Estrutural do Magmatismo em Zonas de Cisalhamento. PhD Thesis, Instituto de Geociências, Universidade Federal do Rio Grande do Sul, Porto Alegre, $310 \mathrm{p}$

Bitencourt M.F., Bongiolo E.M., Philipp R.P., Morales L.F.G., Rubert R.R., Melo C.L., Luft Jr. J.L. 2008. Estratigrafia do Batólito Florianópolis, Cinturão Dom Feliciano, na Região de Garopaba-Paulo Lopes, SC. Pesquisas em Geociências, 35(1):109-136.

Bitencourt M.F., Hackspacher P.C., Stoll L.V. 1989. A Zona de Cisalhamento Major Gercino - Santa Catarina. In: Simp. Nac. Est. Tect, 2. Fortaleza, Annals, p. 214-215

Bournas N., Galdeano A., Hamoudi M., Baker H. 2003. Interpretation of the aeromagnetic map of Eastern Hoggar (Algeria) using the Euler deconvolution, analytic signal and local wave number methods. Journal of African Earth Sciences 37:191-205

Briggs I.C. 1974. Machine contouring using minimum curvature. Geophysics, 39(1):39-48.

Carneiro C.C., Crósta A.P., Silva A.M., Pinheiro R.V.L. 2006. Fusão de imagens altimétricas e aeromagnetométricas como ferramenta de interpretação geológica, exemplo da Província Mineral de Carajás (PA). Revista Brasileira de Geofísica, 24(2):261-271.

Castro N.A., Crósta A.P., Ferreira F.J., Basei M.A.S., Pascholati M.E. 2003. Quadro geológico regional da porção do Embasamento PréOrdoviciano de Santa Catarina com base em imagens Landsat-5/ TM e aerogeofísicas. Revista Brasileira de Geociências, 33(Suppl 2):161-172

Cordell L. \& Grauch V.J.S. 1985. Mapping basement magnetization zones from aeromagnetic data in the San Juan Basin, New México. In: Hinze W.J. (ed.). The Utility of Regional Gravity and Magnetic Anomalies Maps. Tulsa, Oklahoma, Society of Exploration Geophysics, p. 181-197.

CPRM - Serviço Geológico do Brasil. AERO Data Base. Available from: www.cprm.gov.br/aero/aero.htm. Cited 2009 April 17

Farr T.G., Rosen P.A., Caro E., Crippen R., Duren R., Hensley S., Kobrick M., Paller M., Rodriguez E., Roth L., SeaL D., Shaffer S., Shimada J., Umland J., Werner M., Oskin M., Burbank D., Alsdorf D. 2007. The Shuttle Radar Topography Mission. Review of Geophysics, 45(2):21-35.

Ferreira F.J.F. 1982. Integração de dados aeromagnéticos e geológicos: configuração e evolução tectônica do Arco de Ponta Grossa. MS Dissertation, Instituto de Geociências, Universidade de São Paulo, São Paulo, 170 p.

Ferreira F.J.F., Souza J., Bongiolo A.B.S., Castro L.G., Romeiro M.A.T. 2010. Realce do gradiente horizontal total de anomalias magnéticas usando a inclinação do sinal analítico. Parte I: Aplicação a dados sintéticos. In: SBGf, IV Simpósio Brasileiro de Geofísica, Brasília, Annals, p. 1-6.

Ferreira F.J.F., Souza J., Bongiolo A.B.S., Castro L.G. 2013. Enhancement of the total horizontal gradient of magnetic anomalies using the tilt angle. Geophysics, 78(3):J33-J41.

Fragoso-Cesar A.R.S. 1980. O Cráton Rio de La Plata e o Cinturão Dom Feliciano no Escudo Sul-riograndense. In: SBG, Cong. Bras. Geol., 31, Balneário de Camboriú, Annals, p. 2879-2892. 
Freitas R.C., Rostirolla S.P. 2005. Análise comparativa entre estruturas do embasamento e resposta em superfície na Bacia do Paraná, região entre os Estados do Paraná e Santa Catarina. In: SBG, Simp. Nac. de Estudos Tectônicos, 10; Int. Symp. on Tectonics, 4, Curitiba, Bol Res Exp, v.1, p. 41-44.

Fulfaro V.J., Saad A.R., Santos M.V., Vianna R.B. 1982. Compartimentação e evolução tectônica da Bacia do Paraná. Revista Brasileira de Geociências, 12(4):233-256.

Geosoft. 2010. Montaj GridKnit. Grid stitching extension for Oasis Montaj V7.1. Tutorial and Users guide. p. 32.

Gunn P.J., Fitzgerald D., Yassi N., Dart P. 1997. New algorithms for visually enhancing airborne geophysical data. Exploration Geophysics, 28:220-224.

Hasui Y. 2010. A grande colisão Pré-cambriana do sudeste Brasileiro e a estruturação regional. Geociências, 29(2):141-169.

Heilbron M., Pedrosa-Soares A.C., Campos Neto M., Silva L.C., Trouw R.A.J., Janasi V.C. 2004. A Província Mantiqueira. In: Mantesso-Neto V., Bartorelli A., Carneiro C.D.R., Brito Neves, B.B. (eds.). O desvendar de um continente: a moderna Geologia da América do Sul e o legado da obra de Fernando Flávio Marques de Almeida. São Paulo, Beca, cap. XIII, p. 203-234.

Jacques P.D., Machado R., Nummer A.R. 2010. Lineamentos estruturais na borda leste da Bacia do Paraná em Santa Catarina: Análise multiescala com base em imagens LANDSAT e SRTM. Pesquisa em Geociências, 37(2):117-131.

Jacques P.D., Machado R., Nummer A.R. 2012. A comparison for a multiscale study of structural lineaments in southern Brazil: LANDSAT-7 ETM+ and shaded relief images from SRTM3-DEM. Anais da Academia Brasileira de Ciências, 84(4):931-942.

Li X. 2006. Discussion and reply on theta map: Edge detection in magnetic data. Geophysics, 71(3):X11-X12.

Machado, R. \& Endo I.S. 1993. Cinturão de Cisalhamento Atlântico: Um Exemplo de Tectônica Transpressional Neoproterozóica. In: IV Simpósio Nacional de Estudos Tectônicos, Anais, Belo Horizonte, p. 356-359.

Machado R., Roldan L.F., Jacques P.D., Fassbinder E., Nummer A.R. 2012. Tectônica transcorrente Mesozoica-Cenozoica no Domo de Lages - Santa Catarina. Revista Brasileira de Geociências, 42(4):799-811.

Machado R. \& Teixeira W. 2008. Idades (40Ar/39Ar) do Magmatismo Alcalino do Distrito Alcalino de Lages, SC. In: SBG, Simp. Vulc. e Amb. Assoc. 4, Bol. Res., Foz do Iguaçu.

Medeiros V.C., Medeiros W.E., Sá M.F.J. 2011. Utilização de imagens aerogamaespectrométricas, Landsat 7 ETM + e aeromagnéticas no estudo do arcabouço crustal da porção central do domínio da zona transversal, província Borborema, NE do Brasil. Revista Brasileira de Geofísica, 29(1):83-97.

Milani E.J. 1997. Evolução tectono-estratigráfica da Bacia do Paraná e seu relacionamento com a geodinâmica fanerozóica do Gonduana Sul-Ocidental. PhD Thesis, 2 v., Instituto de Geociências, Universidade Federal do Rio Grande do Sul, Porto Alegre. $254 \mathrm{p}$

Milani E.J. 2004. Comentários sobre a origem e a evolução da Bacia do Paraná. In: Mantesso-Neto V., Bartorelli A., Carneiro C.D.R., Brito Neves B.B. (eds.), Geologia do continente sulamericano: a evolução da obra de Fernando Flávio Marques de Almeida. São Paulo, Beca, p. 265-279.

Milani E.J. \& Ramos V.A. 1998. Orogenias Paleozoicas no domínio sul-ocidental do Gondwana e os ciclos de subsidência da Bacia do Paraná. Revista Brasileira de Geociências, 28:473-484.
Miller H.G. \& Singh V. 1994. Potential field tilt - a new concept for location of potential field sources. Journal of Applied Geophysics, 32:213-217.

Nabighian M.N. 1972. The analytic signal of two dimensional magnetic bodies with polygonal cross-section: Its properties and use for automated anomaly interpretation. Geophysics, 37:507-517

Northfleet A.A., Medeiros R.A., Mülhmann H. 1969. Reavaliação dos dados geológicos da Bacia do Paraná. Boletim Técnico da Petrobras, 12(3):291-346.

Passarelli C.R. \& Basei M.A.S. 1995. Análise dos petrotramas de eixos-c de quartzo: Zona de Cisalhamento Major Gercino (SC). Boletim IG-USP. Série Cientifica, 26:99-113.

Passarelli C.R., Basei M.A.S., Wemmer K., Siga Jr. O., Oyhantçabal P. 2011. Major shear zones of southern Brazil and Uruguay: Escape tectonics in the eastern border of Rio de La plata and Paranapanema cratons during the Western Gondwana amalgamation. International Journal of Earth Sciences, 100(2-3):391-414.

Philipp R.P., Mallmann G., Bitencourt M.F., Souza E.R., Souza M.M.A., Liz J.D., Wild F., Arendt S., Oliveira A.S., Duarte L., Rivera C.B., Prado M. 2004. Caracterização litológica e evolução metamórfica da porção leste do Complexo Metamórfico Brusque, Santa Catarina. Revista Brasileira de Geociências, 34(1):21-34.

Portela Filho C.V., Ferreira F.J.F., Raposo M.I.B., Strugale M. 2005. Estimativa da extensão crustal do Arco de Ponta Grossa com base em modelagens aeromagnéticas na região de ApucaranaPR. In: Simp Nac de Est Tect, 10, Curitiba, Bol. de Res. Exp. p. 134-136.

Quintas M.C.L. 1995. O embasamento da Bacia do Paraná: reconstrução Geofísica de seu arcabouço. PhD Thesis, Instituto de Astronomia e Geofísica, Universidade de São Paulo, 253 p.

Roest W.R.J., Verhoef J., Pilkington M. 1992. Magnetic interpretation using the 3-D analytic signal. Geophysics, 57:116-125

Roldan L.F. 2007. Tectônica Rúptil Meso-Cenozóica na região do Domo de Lages, SC. MS Dissertation, Instituto de Geociências, Universidade de São Paulo, 121 p.

Roldan L.F., Machado R., Steiner S.S., Warren L.V. 2010. Análise de lineamentos estruturais no Domo de Lages (SC) Com Uso de Imagens de Satélite e Mapas de Relevo Sombreado. Geologia USP, 10(2):57-72

Rostirolla S.P., Assine M.L., Fernandes L.A., Artur P.C. 2000. Reativação de paleolineamentos durante a evolução da Bacia do Paraná - o exemplo do Alto Estrutural de Quatiguá. Revista Brasileira de Geociências, 25(2):79-84

Scheibe L.F., Kawashita K., Gomes C.B. 1985. Contribuição à geocronologia do Complexo Alcalino de Lages, SC. In: SBG, Simp. Sul-Bras. Geol., 2, Minutes, Florianópolis, p. 299-307.

Silva L.C. 1991. O Cinturão Metavulcanossedimentar Brusque e a evolução policíclica das faixas dobradas Proterozóicas no sul do Brasil: uma revisão. Revista Brasileira de Geociências, 21:60-73.

Silva L.C. 2006. Geocronologia aplicada ao mapeamento regional, com ênfase na técnica U-Pb SHRIMP e ilustrada com estudos de casos brasileiros. Brasília: CPRM, 132 p. (Publicações Especiais do Serviço Geológico do Brasil). Available from: www.cprm.gov. br. Cited 2011 February 24.

Soares A.P., Barcellos P.E., Csordas S.M. 1982. Lineamentos em imagens de Landsat e Radar e suas implicações no conhecimento tectônico da Bacia do Paraná. In: Simp. Bras. Sens. Remoto, 2, Brasília, p. 143-168. 
Spector A. \& Grant F.S. 1970. Statistical models for interpreting aeromagnetic data. Geophysics, 35(2):293-302.

Strugale M. 2002. Arcabouço e evolução estrutural do Arco de Ponta Grossa no Grupo São Bento (Mesozóico): Implicações na hidrodinâmica do Sistema Aqüífero Guarani e na migração de hidrocarbonetos na Bacia do Paraná. MS Dissertation, Instituto de Geociências, Universidade Federal do Paraná, Curitiba, 154 p.

Strugale M., Rostirolla S.P., Mancini F., Portela Filho C.V., Ferreira F.J.F., Freitas R.C. 2007. Structural framework and MesozoicCenozoic evolution of Ponta Grossa Arch, Paraná Basin, southern Brazil. Journal of South American Earth Sciences, 24:203-227.

Vasconcellos R.M., Metelo M.J., Motta A.C., Gomes R.D. 1994. Geofísica em levantamentos geológicos. Rio de Janeiro, CPRM, $165 \mathrm{p}$.
Verduzco B., Fairhead C., Green C., Mackenzie C. 2004. New insights into magnetic derivatives for structural mapping. The Leading Edge, 23:116-119.

Zalán P.V., Wolff S., Conceição J.C.J., Astolf M.A.M., Vieira I.S., Appi V.T., Zanotto O.A., Marques A. 1991. Tectonics and sedimentation of the Paraná Basin. In: Gondwana Symposium, 7, São Paulo, Proceedings, p. 83-117.

Zalán P.V., Wolff S., Conceição J.C., Marques A., Astolf M.A.M., Vieira I.S., Appi V.T. 1990. Bacia do Paraná. In: Origem e evolução de Bacias Sedimentares. Rio de Janeiro, Petrobras, p. 135-164.

Zalán P.V., Wolff S., Conceição J.C.J., Vieira I.S., Appi V.T., Zanotto O.A. 1987. Tectônica e Sedimentação da Bacia do Paraná. In: SBG, Simp. Sul-Bras. Geol., 3, Curitiba, Minutes, p. 441-474.

Arquivo digital disponível on-line no site www.sbgeo.org.br 